\title{
The Effect of Teaching Strategies and Students Curiosity on Students' Achievement in Reading Comprehension
}

\author{
Fitri Ervina Tarigan', Ika Vanesia Siagian², Badriyyah Jamil Tanjung ${ }^{3}$, Ahmad Rozik ${ }^{4}$ \\ 1,2,3,4 Medan State University, Indonesia \\ Corresponding Author : Fitriervinatarigan@gmail.com
}

\begin{tabular}{|c|c|}
\hline & ABSTRACT \\
\hline & $\begin{array}{l}\text { The objective of this research was to investigate whether: (1) The students' } \\
\text { achievement in reading comprehension taught by using INSERT strategy was } \\
\text { higher than that taught by using K-W-L strategy, (2) The students' achievement } \\
\text { in reading comprehension with high curiosity was higher than that low curiosity, } \\
\text { and (3) There was interaction between teaching strategies and curiosity on the } \\
\text { students' achievement in reading comprehension. This study was conducted at } \\
\text { SMP Al-Ulum Medan during academic year } 2017 / 2018 \text {. The population of this } \\
\text { study was the eighth grade student which consists of six classes namely VIII-1, } \\
\text { VIII-2, VIII-3, VIII-4, VIII-5, and VIII- } 6 \text {. So, the total of population was } 228 \\
\text { students. Then two classes of grade VIII- } 4 \text { and VIII- } 6 \text { were chosen in this study as } \\
\text { the sample. This study was an experimental research. The instrument used in this } \\
\text { research was reading comprehension test and questionnaire sheet. The data were } \\
\text { analysed by using two ways analysis of variance (Anova) } 2 \times 2 \text { factorial design F- } \\
\text { test at the level of significant } 5 \% \text { or a }=0.05 \text {. The result of data analysis proved } \\
\text { that: The students' achievement in reading comprehension taught by using } \\
\text { INSERT strategy was higher than that taught by using K-W-L strategy, (2) The } \\
\text { students' achievement in reading comprehension with high curiosity was higher } \\
\text { than that low curiosity, and (3) There was interaction between teaching strategies } \\
\text { and curiosity on the students' achievement in reading comprehension by } \\
\text { observing the data analysis, and the scores means of the students. }\end{array}$ \\
\hline & Teaching Strategies, Student, Reading \\
\hline
\end{tabular}

\section{INTRUDUCTION}

Reading is the foundation of all knowledge and the foundation for a proper education. Good reading can be helpful to obtain the current information as it necessary. However, if people can read, yet is not really able to interpret what is read into usable information, they have not gained much until they have good reading skill. Because the information is a part of communication process of getting the thoughts that were in author's mind into reader's mind. Without comprehension, reading is simply following words on a page from left to right while sounding them out; the word on page have no meaning. Thus, reading comprehension has involved understanding what is being read, since the main objective of reading comprehension is to gain some understanding of what the writer is trying to convey and can utilize that information

However reading comprehension is not yet achieved, for some readers comprehension is always challenging. They may understand the word 
separately, but linking them together into the meaningful ideas often does not happen as it should. These readers can decode the words, but have not developed sufficient skill to comprehend deeper meaning of sentences, the paragraph and the entire text. Reading can be challenging particularly when the material is unfamiliar, technical or complex, moreover from them who have several reading problem that included inability to pronounce words, limited academic vocabulary, and difficulty applying literal and critical comprehension skills when processing text. The deficiencies are in Indonesian student that cause the lack of ability in reading comprehension proved by the data that has been observed showed in International Students' Achievement in Reading, the reading score of Indonesian Student as reported by PIRL (Progress in International Reading Literacy,2006) is low, Indonesia got the fourth lowest rank from 45 countries that indirectly reveals that Indonesia students have a problem in reading.

In the same fact, research on reading skill in Indonesia has revealed that the students' skills particularly in reading comprehension are far from satisfactory. It is as reported in Kompas, a daily newspaper 2007 that around 37,6\% of 15-years old students are merely able to read a text without understanding the meaning carried by the text. Only $24.8 \%$ out of them are able to correlate the test with the prior Knowledge. It means that many students still have insufficient ability to comprehend the text.

The reality is there are so many students who are able to read the text wuth the appropiate pronounciation but they do not know what they are reading about. It is because they do not apply the way use when reading in their native languange to reading in the foreign languange they are leraning. They just spent their time to earn the meaning word by word, then consult the unknown vocabularies continue with the meaning of each sentences. Actually what it si done by them just touch the linguistic knowledge. This is actually the phenomenon teacher faced in the class included in SMP Swasa Al-Ulum. The phenomenon is seen in the following table.

Table 1.The Reading Comprehension Score of Eighth Grade Students of SMP Al-Ulum in 2017/2018 Academic Year

\begin{tabular}{|lcccc|}
\hline $\begin{array}{l}\text { Semester } \\
\text { Reading }\end{array}$ & \multicolumn{4}{c|}{ Means of students' achievement in languange learning } \\
& Speaking & Listening & Writing & \\
\hline I & 65 & 60 & 60 & 65 \\
\hline
\end{tabular}

As long as the academic year 2017-2018 its found that the average score of student achievement in reading comprehension in the first semester on $2017 / 2018$ of school year was 65 whereas the completeness score of students' 
achievement in reading comprehension is 75 It means that the students achievements in reading still nder Minimal Passing Grade Criteria ( Kriteria Ketuntasan Mnimal :KKM) The lowness of students' achievement in comprehending the text is caused the students get bored directly when the text is given to them. As result. They are less interested in further activities related with the reading text. The facts shows that strategies which are challenging the students are needed so that they are more curious in reading class.

According to Alexander (1998) reading comprehension is influenced by many factors, among others are reading material, the total program of reading instructions, the children own personality, attitudes, interest, motivation, habits and his out of school environtment influence the development of reading comprehension.

In order to overcome this problem, teacher should find the suitable reading comprehension strategy. A reading comprehension strategy is a cognitive or behavioural action that is enacted under particular contextual condition; with the goal of improving some aspect of comprehension (Danielle, 2007:6). There are many reading comprehension strategies which have been used by lots of researchers, for instance Interactive Notation System for Effective Reading and Thinking (INSERT) strategy. This strategy uses symbols or notation like check mark or sign. It is used as a way for the reader to respond to the text while they are reading. They will relate what they know previously to new information which can be found in the text. Beside that this strategy help them to identify what they do not know or which one that make them feel confused from the text while reading is processed.

Another strategy is Know, Want, Learn or also known as K-W-L. The letters K-W-L are an acronym for 'what we know', what we want to know and 'what we learn'. It is suitable all subject. This strategy can help students to organize information before, during, and after a unit or a lesson. It can be used to engage students in a new topic, activate their prior knowledge, share unit objectives and monitor students' learning in the classroom.

Beside the teaching strategy, another factor that influence the reading comprehension is the students own personality. Curiousity is one of the students' personalities that includes and related in learning process. Curiousity, undoubtly is a personal factors that realy affects the succes of teaching and learning in the classroom.When learner's curiosity is well provoked they will have great wander through the tasks given by the teachers, new sensation directed towards the process of learning, positive behaviour, and better concentration and attetion while teaching and learning process occur. Those attitudes of course are considered as strong motivation to facilitate cognitive, 
affective, and psychomotors developments in teaching and learning any skilss, including reading comprehension.

When the students are exposed to INSERT and K-W-L strategies in comprehending the text, they, actually are treated to be information seekers since they must be aware of what they know and what they believe. Beside that they must confront what they know and believe with the information conveyed by the writer in a text.

Based on the explanation above, it can be stated that teaching strategies and the level of students' curiosity significantly affect students' reading comprehension achievement. Thus, in this study the researcher is interested in discovering the effect INSERT and K-W-L strategies in improving the students' reading comprehension for those who have high and low curiousity.

\section{RESEARCH METHOD}

The design used in this study is quantitative approach with an experimental design. According to Margono (2000:10) experimental research is a research that is a research that conducted by experiments on the experimental group.This study uses factorial design $2 \times 2$ in order to compare two teaching strategies (namely INSERT and K-W-L) and the students' curiosity. Furthermore, there are three variables in this study. They are independent variables (INSERT and K-WL strategies), moderator variables (students' curiosity, high and low), and dependent variables (reading comprehension). The research design was presented through the table below:

Table 2. Factorial Research Design $2 \times 2$.

\begin{tabular}{|l|l|l|}
\hline $\begin{array}{l}\text { Teaching Strategies (A) } \\
\text { Students' Curiosity (B) }\end{array}$ & INSERT Strategy (A1) & K-W-L Strategy (A2) \\
\hline High (B1) & A1B1 & A2B1 \\
\hline Low (B2) & A1B2 & A2B2 \\
\hline
\end{tabular}

Note:
A : Teaching Strategy
B : Curiosity
A1 : INSERT Strategy
A2 : K-W-L Strategy
B1 : Students that have high curiosity
B2 : Students that have lo curiosity
A1B1 : Students who have high curiosity are taught by using INSERT Strategy
A2B1 : Students who have high curiosity are taught by using K-W-L Strategy 
Cybernetics: Journal of Research and Educational Studies

Volume 2 Nomor 4, Oktober 2021

Halaman 66-80

A1B2 : Students who have low curiosity are taught by using INSERT Strategy

A2B2 : Students who have low curiosity are taught by using K-W-L Strategy

Population and Sample

According to Sugiyono (2013: 117), population is the generalization area which consists of: object/ subject which had the quality or certain characteristic which was set by the researcher to be studied and then taken the conclusion.This study was conducted in SMP Al-Ulum Medan. It is located atJl. Amaliun Gg. Johar No. 21,22 Medan Area, Kota Medan, Sumatera Utara. The population of the study was all the students in the VIII grade academic year 2017/2018 on the first semester. There were 6 classes, namely VIII-1, VIII-2, VIII-3, VIII-4, VIII-5, and VIII-6. And the total number of population was 228 students. Then two classes of grade VIII-4 and VIII-6 were chosen in this study as the sample.

\section{Procedure of Treatment}

The sample of the research were in the same school, range of age, and the parallel classes. They also have the same length of time for the treatment that is $2 \times 40$ minutes. It was conducted in sixth meetings. Before giving treatment to the students, the writer introduced and explained about the steps of INSERT strategy and Know-Want to Know-Learn (KWL) strategy in teaching reading.

Table 3. The Treatment

\begin{tabular}{|c|c|}
\hline INSERT Strategy & $\begin{array}{c}\text { Know - Want to Know - Learn } \\
(\text { KWL) Strategy }\end{array}$ \\
\hline $\begin{array}{l}\text { 1. Explaining to the students } \\
\text { what the INSERT strategy } \\
\text { symbols mean and how they } \\
\text { can use them to mark/code } \\
\text { text while reading, students } \\
\text { make the following INSERT } \\
\text { notation during reading. }\end{array}$ & $\begin{array}{l}\text { 1. Naming the topic, and asking } \\
\text { students to think of what the } \\
\text { already know about it, it helps } \\
\text { to have students list their } \\
\text { ideas, and to share their ideas } \\
\text { with a partner before they } \\
\text { answer. }\end{array}$ \\
\hline $\begin{array}{l}\text { 2. The students read, recorded } \\
\text { symbols, and created their } \\
\text { own insert summary charts. }\end{array}$ & $\begin{array}{l}\text { 2. Create a K-W-L chart on the } \\
\text { chalk board or on chart paper. }\end{array}$ \\
\hline $\begin{array}{l}\text { 3. They compare their charts } \\
\text { with one or two peers. } \\
\text { Discussion based on these } \\
\text { chart will help to clarify } \\
\text { information for students. }\end{array}$ & $\begin{array}{l}\text { 3. Create a K-W-L chart on the } \\
\text { chalk board or on chart paper. }\end{array}$ \\
\hline $\begin{array}{l}\text { 4. After comparing INSERT } \\
\text { charts, students might } \\
\text { recognize their post-notes to }\end{array}$ & $\begin{array}{l}\text { 4. Now ask students to think of } \\
\text { questions they have about } \\
\text { topic. They may begin by }\end{array}$ \\
\hline
\end{tabular}




\begin{tabular}{|c|c|}
\hline $\begin{array}{l}\text { reflect how the information } \\
\text { they have recorded is related, } \\
\text { producing a concept map or } \\
\text { graphic organizer. }\end{array}$ & $\begin{array}{l}\text { reviewing what they know, } \\
\text { and finding areas where their } \\
\text { knowledge is incomplete. } \\
\text { Write their questions on the } \\
\text { chart in the column marked } \\
\text { what do we want to know? } \\
\text { Feel free to add some of your } \\
\text { own. }\end{array}$ \\
\hline & $\begin{array}{l}\text { 5. The students should now read } \\
\text { the text (listen to a lecture, or } \\
\text { do some others kinds of } \\
\text { investigation). They are } \\
\text { reminded to look for answer to } \\
\text { their questions, and for any } \\
\text { new ideas they did not } \\
\text { anticipate. }\end{array}$ \\
\hline & $\begin{array}{l}\text { 6. The students report the things } \\
\text { they learned from the text. } \\
\text { First they report answer they } \\
\text { found to their questions, and } \\
\text { then they report any other } \\
\text { interesting or important ideas } \\
\text { they discovered. The teacher } \\
\text { records these on the chart in } \\
\text { the column labelled what did } \\
\text { we learn? }\end{array}$ \\
\hline
\end{tabular}

\section{Technique Collecting Data}

\section{Instrument of Collecting the Data}

Sugiyono (2011: 148) states that instrument was a tool to measure nature phenomenon or social that was observed. The instruments used in this study were the instrument of questionnaire to investigate students' curiosity and multiple choice questions as the instrument of reading comprehension test.

\section{Questionnaire of Curiosity}

Students' curiosity was defined based on their interest questionnaires test scores that investigated by using likert scale form. A likert scale was an ordered scale from which respondents chosen one option the best aligns with their view (Losby and Wetmore, 2012) 
Cybernetics: Journal of Research and Educational Studies

Volume 2 Nomor 4, Oktober 2021

Halaman 66-80

The statement was consisted of four options, from the lowest to the highest statement. The option scored 4 for option Strongly Agree (SangatSetuju: SS), 3 for option Agree (Setuju: S), 2 for option Disagree (TidakSetuju: TS), and 1 for option Strongly Disagree (SangatTidakSetuju: STS). The questionnaire consists of 20 statements.

Table 4. Specification of Curiosity Statement.

\begin{tabular}{|l|l|l|l|}
\hline No. & Indicators & Item Numbers & Total \\
\hline 1 & Situational Curiosity & $1,4,7,10,13$ & 5 \\
\hline 2 & Individual Curiosity & $2,5,8,11,14$ & 5 \\
\hline 3 & Topic Curiosity & $3,6,9,12,15,16,17,18,19,20$ & 10 \\
\hline & Total & & $\mathbf{2 0}$ \\
\hline
\end{tabular}

\section{Reading Comprehension Test}

To measure students' reading comprehension test will be administrated. Reading comprehension test that is used in this research is multiple choice test. The numbers of test are 20 items through recount text as the genre. It could be seen in the table below:

Table 4. The Indicators of Reading Comprehension

\begin{tabular}{|c|c|c|c|}
\hline No. & Indicators & ItemNumbers & Total \\
\hline 1 & Identifying main idea & 2 & 1 \\
\hline 2 & Identifying supporting details & $1,3,4,5,6,7,8,9$ & 8 \\
\hline 3 & Understanding meaning & 10 & 1 \\
\hline & Total & & 10 \\
\hline
\end{tabular}

\section{Technique of Analysing the Data}

The techniques of analysing the data in this research were descriptive statistics and inferential technique. Descriptive statistical technique was used to describe the data, they are: mean, median, mode, and standard deviation. Inferential statistic technique was used to examine the research hypothesis by using two ways analysis of variance (Anova) $2 \times 2$ factorial design F-test at the level of significant $5 \%$ or $a=0.05$.Below was the relationship among hypothesis, research problems, and technique of analysing the data. 
Table 5. The Relationship among Hypothesis, Research Problem, and Technique of Analysing the Data.

\begin{tabular}{|c|c|c|c|c|}
\hline No. & Research Problems & Hypothesis & $\begin{array}{c}\text { Group of } \\
\text { Data }\end{array}$ & $\begin{array}{c}\text { Technique of } \\
\text { Analysing the } \\
\text { Data }\end{array}$ \\
\hline 1 & $\begin{array}{l}\text { Is the students' achievement in } \\
\text { reading comprehension that is } \\
\text { taught by using INSERT } \\
\text { strategy significantly higher } \\
\text { than that is taught by using } \\
\text { Know-Want to Know-Learn (K- } \\
\text { W-L) strategy? }\end{array}$ & 1 & $\mathrm{~A}_{1}, \mathrm{~A}_{2}$ & $\begin{array}{c}\text { Two-way } \\
\text { Anova }\end{array}$ \\
\hline 2 & $\begin{array}{l}\text { Is the students' achievement in } \\
\text { reading comprehension with } \\
\text { high curiosity higher than with } \\
\text { low curiosity? }\end{array}$ & 2 & $\mathrm{~B}_{1}, \mathrm{~B}_{2}$ & $\begin{array}{c}\text { Two-way } \\
\text { Anova }\end{array}$ \\
\hline 3 & $\begin{array}{l}\text { Is there any significant } \\
\text { interaction between teaching } \\
\text { strategies and students' } \\
\text { curiosity on reading } \\
\text { comprehension achievement? }\end{array}$ & 3 & $\begin{array}{l}A_{1} B_{1} \\
A_{1} B_{2} \\
A_{2} B_{1} \\
A_{2} B_{2}\end{array}$ & $\begin{array}{c}\text { Two-way } \\
\text { Anova }\end{array}$ \\
\hline
\end{tabular}

\section{Statistical Hypothesis}

The statistical hypothesis testing would be formulated as the following:

$\mathrm{H}_{0}$ : There is not effect in improving the students' achievement in reading recount text for high and low students' curiosity after taught by INSERT Strategy and K-W-L Strategy.

$\mathrm{H}_{\mathrm{a}}$ : There is not effect in improving the students' achievement in reading recount text for high and low students' curiosity after taught by INSERT Strategy and K-W-L Strategy.

If probability $>0.05$, it means that $\mathrm{H} 0$ received. If probability $<0.05$, it means that $\mathrm{H} 0$ rejected. 
Cybernetics: Journal of Research and Educational Studies

Volume 2 Nomor 4, Oktober 2021

Halaman 66-80

\section{RESULT AND DISCUSSION}

\section{The Data Collection}

The data were the students score in the pre-test and post-test. Both the experimental were given pre-test and post-test in form of reading text. The data also the students who have high and low curiosity based on the questionnaire result.

\section{Students' Curiosity}

After distributing the questionnaire about students motivation at the twelfth grade students of MTs Al-Ulum Medan, the researcher got the result of from 20 students 10 have high motivation and 10 have less motivation.

Table 6. The Result of Students' Curiosity.

\begin{tabular}{|c|c|c|}
\hline Students' Initial Name & Result & Criterion \\
\hline CS & 4.6 & High \\
\hline MA & 4.7 & High \\
\hline YPR & 4.3 & High \\
\hline F & 4.5 & High \\
\hline RAH & 5 & High \\
\hline FNL & 4.9 & High \\
\hline NHA & 4.5 & High \\
\hline M & 4.1 & High \\
\hline MC & 4.9 & High \\
\hline ATI & 4.8 & High \\
\hline AF & 2.1 & Low \\
\hline MND & 2.5 & Low \\
\hline NAH & 2.3 & Low \\
\hline D & 1.4 & Low \\
\hline SN & 1.7 & Low \\
\hline MHI & 2.5 & Low \\
\hline SHA & 2.7 & Low \\
\hline WE & 1.9 & Low \\
\hline ITM & 1.6 & Low \\
\hline MFR & 1.8 & Low \\
\hline & &
\end{tabular}

Students' Result Pre-test

Based on the result of collecting data which was gotten in pre-test the researcher found that there is a difference achievement between high students' motivation and low students motivation in VIII-4. 
Cybernetics: Journal of Research and Educational Studies

Volume 2 Nomor 4, Oktober 2021

Halaman 66-80

Table 7. The Result of Pre-test in VIII-4.

\begin{tabular}{|c|c|}
\hline Students Initial Name & Score \\
\hline CS & 70 \\
\hline MA & 70 \\
\hline YPR & 30 \\
\hline F & 40 \\
\hline RAH & 70 \\
\hline AF & 60 \\
\hline MND & 80 \\
\hline NAH & 70 \\
\hline D & 30 \\
\hline SN & 20 \\
\hline
\end{tabular}

In VIII-6, the researcher also found the difference students result between high and low students' motivation and it is drawn from the table below.

Table 8. The Result of Pre-test in VIII-6.

\begin{tabular}{|c|c|}
\hline Students Initial Name & Score \\
\hline FNL & 50 \\
\hline NHA & 40 \\
\hline M & 40 \\
\hline MC & 40 \\
\hline ATI & 40 \\
\hline MHI & 10 \\
\hline SHA & 50 \\
\hline WE & 20 \\
\hline ITM & 50 \\
\hline MFR & 70 \\
\hline
\end{tabular}

\section{Students' Result Post-test}

Based on the result of collecting data which was gotten in post-test the researcher found that there is a difference achievement between high students' motivation and low students motivation in VIII-4.

Table 9. The Result of Post-test in VIII-4.

\begin{tabular}{|c|c|}
\hline Students Initial Name & Score \\
\hline CS & 90 \\
\hline MA & 90 \\
\hline YPR & 90 \\
\hline
\end{tabular}


Cybernetics: Journal of Research and Educational Studies

Volume 2 Nomor 4, Oktober 2021

Halaman 66-80

\begin{tabular}{|c|c|}
\hline F & 70 \\
\hline RAH & 90 \\
\hline AF & 90 \\
\hline MND & 90 \\
\hline NAH & 90 \\
\hline D & 70 \\
\hline SN & 90 \\
\hline
\end{tabular}

In VIII-6, the researcher also found the difference students result between high and low students' motivation and it is drawn from the table below.

Table 10. The Result of Post-test in VIII-6

\begin{tabular}{|c|c|}
\hline Students Initial Name & Score \\
\hline FNL & 50 \\
\hline NHA & 40 \\
\hline M & 40 \\
\hline MC & 40 \\
\hline ATI & 40 \\
\hline MHI & 10 \\
\hline SHA & 50 \\
\hline WE & 20 \\
\hline ITM & 50 \\
\hline MFR & 70 \\
\hline
\end{tabular}

\section{Hypothesis Testing}

Hypothesis testing is done to prove whether there is a significant effect of INSERT strategy and K-W-L strategy for high and low students' curiosity in reading recount text. If there is a significant effect, the researcher wanted to prove that even though there is not a significant effect but those strategies also can give the improvement for students in reading recount text in some students in different Curiosity. It can be proven from this chart below: 
Cybernetics: Journal of Research and Educational Studies

Volume 2 Nomor 4, Oktober 2021

Halaman 66-80

\begin{tabular}{|r|r|r|r|r|}
\hline \multicolumn{6}{|c|}{ Inserthigh } \\
& $\begin{array}{c}\text { Frequenc } \\
\mathrm{y}\end{array}$ & Percent & $\begin{array}{c}\text { Valid } \\
\text { Percent }\end{array}$ & $\begin{array}{c}\text { Cumulative } \\
\text { Percent }\end{array}$ \\
\hline Valid 70,00 & 1 & 20,0 & 20,0 & 20,0 \\
90,00 & 4 & 80,0 & 80,0 & 100,0 \\
Total & 5 & 100,0 & 100,0 & \\
\hline
\end{tabular}

\begin{tabular}{|r|r|r|r|r|}
\multicolumn{7}{|c|}{ Kwlhigh } \\
\hline & $\begin{array}{c}\text { Frequenc } \\
\mathrm{y}\end{array}$ & Percent & $\begin{array}{c}\text { Valid } \\
\text { Percent }\end{array}$ & $\begin{array}{c}\text { Cumulative } \\
\text { Percent }\end{array}$ \\
\hline Valid 60,00 & 2 & 40,0 & 40,0 & 40,0 \\
70,00 & 1 & 20,0 & 20,0 & 60,0 \\
90,00 & 2 & 40,0 & 40,0 & 100,0 \\
Total & 5 & 100,0 & 100,0 & \\
\hline
\end{tabular}

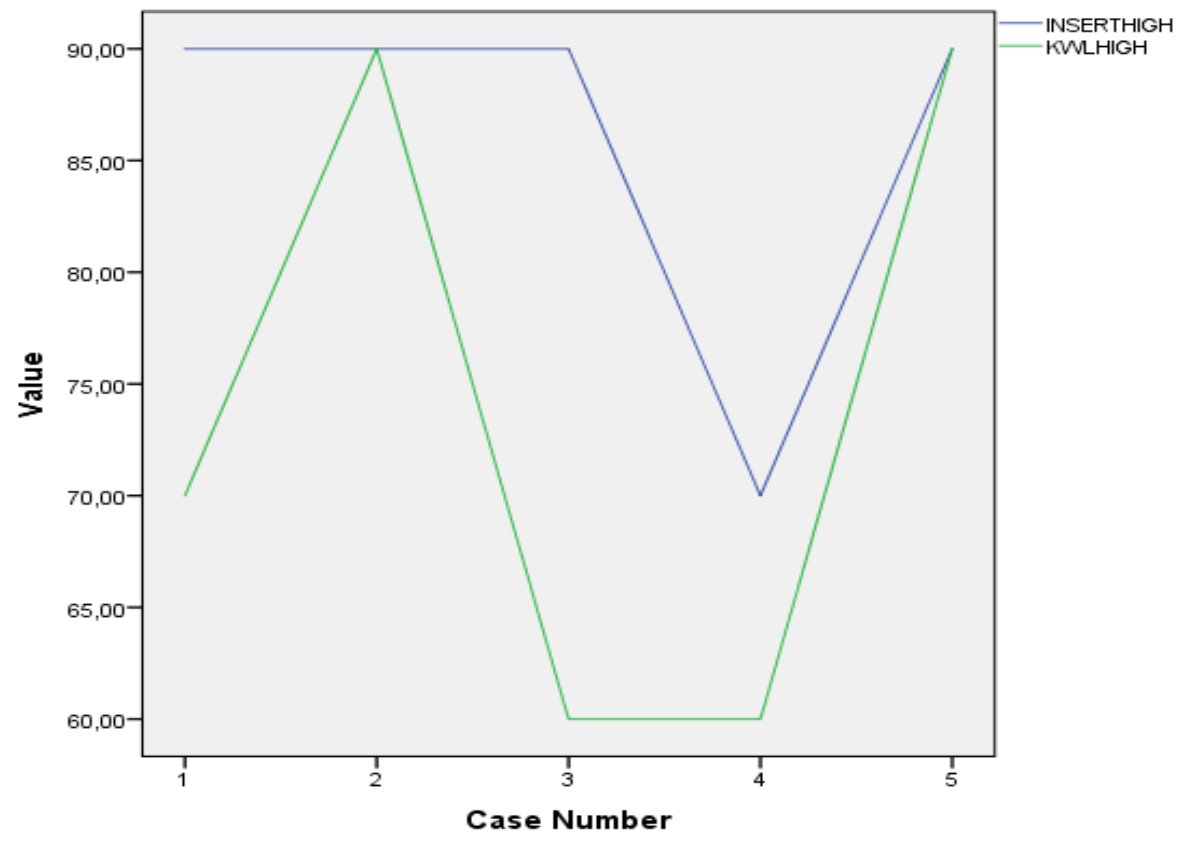


Cybernetics: Journal of Research and Educational Studies

Volume 2 Nomor 4, Oktober 2021

Halaman 66-80

\begin{tabular}{|r|r|r|r|r|}
\multicolumn{7}{|c|}{ Insertlow } \\
\hline & $\begin{array}{c}\text { Frequenc } \\
\text { y }\end{array}$ & Percent & $\begin{array}{c}\text { Valid } \\
\text { Percent }\end{array}$ & $\begin{array}{c}\text { Cumulative } \\
\text { Percent }\end{array}$ \\
\hline Valid 70,00 & 1 & 20,0 & 20,0 & 20,0 \\
90,00 & 4 & 80,0 & 80,0 & 100,0 \\
Total & 5 & 100,0 & 100,0 & \\
\hline
\end{tabular}

\begin{tabular}{|r|r|r|r|r|}
\hline \multicolumn{1}{|c|}{ Kwllow } \\
\hline & $\begin{array}{c}\text { Frequenc } \\
\mathrm{y}\end{array}$ & Percent & $\begin{array}{c}\text { Valid } \\
\text { Percent }\end{array}$ & $\begin{array}{c}\text { Cumulative } \\
\text { Percent }\end{array}$ \\
\hline Valid 60,00 & 1 & 20,0 & 20,0 & 20,0 \\
70,00 & 1 & 20,0 & 20,0 & 40,0 \\
80,00 & 1 & 20,0 & 20,0 & 60,0 \\
90,00 & 2 & 40,0 & 40,0 & 100,0 \\
Total & 5 & 100,0 & 100,0 & \\
\hline
\end{tabular}

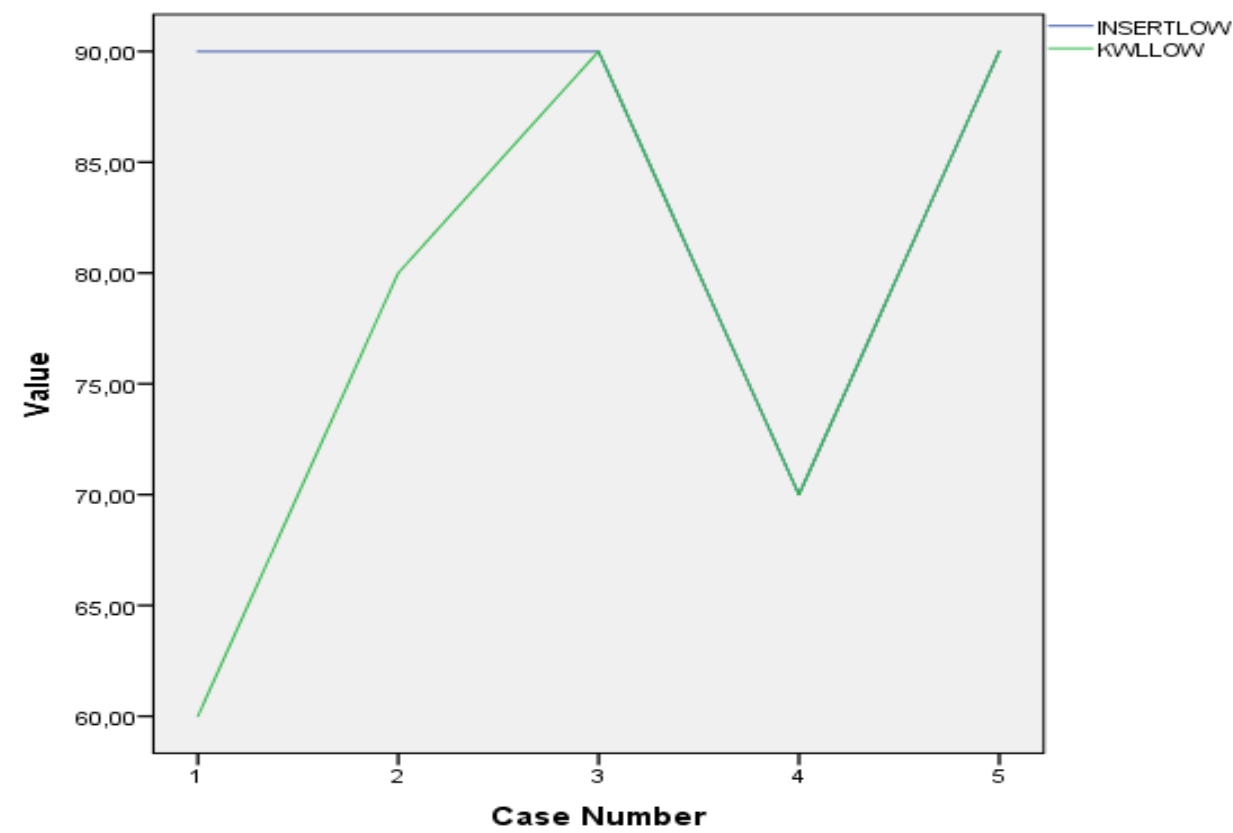


Cybernetics: Journal of Research and Educational Studies

Volume 2 Nomor 4, Oktober 2021

Halaman 66-80

\section{CONCLUSION}

1. answer the research questions that using INSERT strategy is more effective in teaching reading comprehension than using $\mathrm{K}-\mathrm{W}$-L strategy in Al-Ulum Junior High School eighth grade students . It can be concluded that the use of INSERT strategy in reading comprehension is quite success. It can be seen on the chart of students using INSERT strategy graphic that the students who learn reading comprehension by using INSERT is better than K-W-L strategy.

2. This research also provides that reading comprehension of high students' curiosity is higher than low curiosity.

3. There is also the interaction between teaching strategies and the students with low and high curiosity. Which is showed that Insert strategy is matched with high curiosity students and KWL strategy with Low curiosity students

\section{SUGGESTION}

In connection with the conclusion there are some suggestion staged as the following:

1. English teachers are recommended using INSERT strategy and K-W-L strategy in teaching reading comprehension.

2. The teachers are expected to be creative person in order to make the teaching and learning process more interesting,effective, and comfortable for students.

3. English teachers should encourage students have low curiosity to participate in Study English in order to get better achievement in reading comprehension.

\section{REFERENCE}

Macgrus, Adib. Fondasi Keluarga Sakinah, Jakarta: Subdit Bina Keluarga Sakinah, 2019.

Rahima. Modul Pendidikan Keluarga Sakinah, Jakarta: Depaq RI, 2009.

Sarong, Hamid. Hukum Perkawinan Islam di Indonesia, Banda Aceh :Divisi penerbitan,2004.

Basyir, A.Azhar. Hukum Perkawinan Islam,cet IX. Yogyakarta: UII Press,1991.

Hasan, Ali. Pedoman Hidup Berumah Tangga dalam Islam, Jakarta: press

Buku UU Perkawinan 1974 Negara Republik Indonesia bab I pasal I.

Hidayat, Yusuf. Panduan Pernikahan Islami,Guepedia Publisher,2019.

Hermawati, Nunik. Menikah untuk Bahagia, Jakarta Selatan: Mizan Digital, 2018.

Al-Mazhari, Mahmud. Bekal Pernikahan, Jakarta: Qisthi Press,2010.

Januar, Iwan. Tips Meraih Pernikahan Sakinah, Jakarta: Mediati, cet I, 2016.

Al-Mazhari, Mahmud, Perkawinan Idaman, Jakarta: Qisthi Press, 2010. 
Cybernetics: Journal of Research and Educational Studies

Volume 2 Nomor 4, Oktober 2021

Halaman 66-80

ASM, Syaifuddin, Membangun Keluarga Sakinah, Tanggerang: Agromedia Pustaka, 2013.

Dipetik, dari www.dalamislam.com:http://dalamislam.com/hukum-islam/ pernikahan/ / keluarga-sakinah- mawaddah-wa-rahmah Mishba. (2015).

Dipetik dari www.mishba7.com: http://mishba7.com/2015/10/pengertian-sakinahmawaddah-warahmah- pernikahan.html?m=1 Takariawan, C. (2015, April 02).

Subhan Zaituna, Membina Keluarga Sakinah., Yogyakarta: Pustaka Pesantren, 2004. 